\title{
Developing Empathy with STEAM Learning in Grade VIII SMP Lazuardi Al-Falah Depok
}

\author{
Febriandrini Kumala* \\ Lazuardi Al Falah, Depok, Indonesia \\ febriandrini @lazuardialfalah.sch.id \\ *Corresponding author*
}

\begin{tabular}{|c|c|}
\hline Article Info & ABSTRACT \\
\hline Article history: & \multirow{9}{*}{$\begin{array}{l}\text { Empathy (Burns and Lesseig, 2017) is a skill that is rarely discussed } \\
\text { in planning mathematics lessons. The objective of this research is to } \\
\text { initiate and explore how mathematics learning can develop empathy } \\
\text { skills to students using STEAM based project. This research use } \\
\text { qualitative method, in which the observation was executed when } \\
\text { students were developing until launching the application prototype to } \\
\text { a limited audience. The application created with Google Sheets was } \\
\text { called "Your Energy Counter", intended to count the energy gathered } \\
\text { from the food consumed by the user. This research revealed how } \\
\text { empathy was formed during the project execution and how students } \\
\text { are able to reflect on themselves being empathetic to others during } \\
\text { mathematics lessons. }\end{array}$} \\
\hline Received May 30, 2021 & \\
\hline Revised Oct 28, 2021 & \\
\hline Accepted Oct 29, 2021 & \\
\hline Keywords: & \\
\hline STEAM Learning & \\
\hline Empathy & \\
\hline Technology integration & \\
\hline Project Based Learr & \\
\hline
\end{tabular}

This is an open access article under the CC BY-SA license.

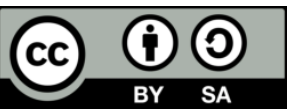

\section{Introduction}

Educating in the era of disruption with technology mastering almost all aspects of human life is not an easy thing. The success of students in the future is influenced not only by their ability to adapt to rapid technological developments, but also from their ability to empathize with themselves and their environment. Technology and empathy are no longer taught separately, but must be fused in every learning activity given by the teacher in the classroom.

In accordance with the direction of the Ministry of Education and Culture, each subject is designed to be integrated with Strengthening Character Education and moving towards the Pancasila Student Profiles, which contain elements of religion, nationalism, independence, mutual cooperation, and integrity (Kemendikbud, 2017). The implications of this policy suggest that teachers can develop learning activities that not only present concepts or theories, but also strengthen students' characters with these five elements. Teaching empathy is one way to start. With empathy, students have the potential to be psychologically motivated to help others who are hit by difficulties because they have the ability to feel or imagine the emotions and feelings experienced by others. So, he will think about how his actions will have an impact on himself and his environment. (Mcdonald \& Messinger, 2013). While in reality, students who enter adolescence have difficulties in developing their 
potential for empathy, especially in seeing that their friends have differences from themselves, so they will have different thoughts and emotions (Piñon \& Forestier, 2018).

Several studies have revealed how educators, in this case teachers and parents, can form empathy for adolescents, including by prioritizing family roles and situations, providing a gaming perspective, using film media, producing films, and through storytelling activities (Auliyah \& Flurentin). , 2016; Ayuni, Siswati, \& Rusmawati, 2013; Boltz, Henriksen, \& Mishra, 2014; Friesem, 2016; Wewengkang \& Moordiningsih, 2016). Designing a game is one way to explore students' empathy skills by creating scenarios needed in game simulations (Belman \& Flanagan, 2010). Other research related to teaching empathy to adolescents suggests designing outdoor activities by telling stories, and putting students in situations experienced by others (R. Harris \& Foreman-Peck, 2004; Van Mechelen, Schut, Gielen, \& Klapwijk, 2018). Empathy can also be taught through drama learning where students try to be able to place themselves and adjust their behavior according to the role they get (Goldstein \& Winner, 2012).

Math class has been known as a class that is not fun, difficult, and even scary to the point that some have a phobia of mathematics (Kurukkan, 2015; Lortie-Forgues, Tian, \& Siegler, 2015; Ojose, 2011). Teaching empathy in math class feels impossible because teachers in Indonesia are accustomed to teaching mathematics in the traditional "top-down" way of instruction, thus leaving no room for students to reason and contribute. The integration of strengthening character education is also complicated by the fact that teachers often hold competitions by giving awards to students who are able to answer quickly and with the right procedures as requested by the teacher (Sembiring, Hadi, \& Dolk, 2008).

One approach to teaching empathy in mathematics classes is to link mathematics learning with design engineering projects (Burns \& Lesseig, 2017; Van Mechelen, Schut, Gielen, \& Södergren, 2019). In their publication, Burns and Lesseig (2017) defines empathy in the design process as placing oneself as the user of the product to be designed, and thinking about the various experiences that the user might experience. In the research of Van Mechelen, et al, empathy is generated by the existence of a common goal so that students will be moved to see what is needed to achieve that goal. Undertaking an engineering project that applies mathematical theory and demonstrates its use in life will be in line with the real goal of learning mathematics, namely teaching mathematics for use (Freudenthal, 1968).

In understanding mathematical concepts, the Realistic Mathematics Education (RME) approach has a higher success rate than traditional learning, and has been proven by research aimed at elementary school students (Sembiring et al., 2008). When implementing projectbased learning, the teacher invites students to see real problems from various sides and engages students in discussions. RME makes students understand concepts better, and project-based learning enhances student experience in real life. The question that will be answered in this research is, "Can empathy be developed with STEAM learning in mathematics class?"

\section{Method}

The research subjects were eleven students of Grade VIII at SMP Lazuardi Al Falah GIS Depok, with the object of research being the attitude and behavior of students' empathy during the engineering design project process, for 4 weeks with a total of 20 hours of lessons. This study uses a qualitative research method, in which students are conditioned to learn with project-based methods and look at the processes that occur during students completing 
projects. The research instrument is the researcher himself who observes the research subject directly, conducts interviews, and records anecdotes during the activity.

The stages of learning activities refer to STEAM project-based learning that integrates science, technology, engineering, and fine arts with mathematics. The STEAM project is carried out in an integrated manner where science and art subjects collaborate on the project. Since getting to know the Google application in 2017, almost all learning at the Blueberry Al Falah Junior High School in Depok has been integrated with technology and at the beginning of the 2019 school year it was fully integrated with Google for Education.

The competencies to be achieved according to the curriculum of the subjects involved are as follows:

a. Mathematics: Solving problems related to relations and functions using various representations.

b. Science: Provides analysis of human energy needs and the adequacy of energy obtained from food.

c. Fine Arts: Presenting infographics in the form of watercolor illustrations, the results of which are scanned into posters using AR (augmented reality) technology.

d. Technology: Creating data-driven app products in Google Sheets integrated with AR posters from Zappar

e. Engineering: Making products that can calculate the energy needed by humans and obtained from food

The learning objectives to be achieved fulfill 6 elements of affirming student involvement in the project, namely:

a. Objective: To create an application for calculating human energy by applying the concepts of mathematics, science, and fine arts according to the basic competencies you want to achieve

b. Role: Being a team member of an application developer, which is divided into 4 divisions, namely the data development division, the program division, the design division, and the marketing division.

c. Audience: For the young public, especially students at Blue Junior High School Al Falah

d. Situation: Many teenagers reduce their food intake, go on a diet because they are afraid that their body will look fat, so that they can't concentrate on studying because of lack of body nutrition.

e. Product: An application that analyzes the body's energy needs with the number of calories of food that enter the body.

f. Standard: Application built in Google Sheets, with publication of an AR poster of the Zappar . application

All 11 students of class VIII SMP Lazuardi Al Falah, of which 1 student has special needs, are conditioned like working in an application development company. The success of a company in developing applications will depend on the accuracy of the work and the completeness of the data it has for processing in other divisions, as well as the readiness of each division to support other divisions. Thus, the ability to empathize is needed to move each individual so as not to become a burden in one division or another.

The students agreed that the name of the company was Saad Corporation (taken from the name of class VIII Sa'ad bin Mu'ad), which has 4 divisions, namely:

a) Data development division: Develop data on the nutritional content of food and native Indonesian food ingredients from the Indonesian Food Composition Data website 
(panganku.org) developed by the Ministry of Health of the Republic of Indonesia, as well as from other websites for certain foods.

b) Program division: Collaborating with science teachers to develop the formula needed to perform an analysis of the calculation of the body's energy needs (J. A. Harris \& Benedict, 1918) and the number of calories accumulated from the food that has been consumed.

c) Design division: Worked with art teachers, collected illustrations from all students, scanned them into the app, and completed an AR-based poster, which has a link to the Google Sheets body energy analysis ap.

d) Marketing division: Creating logos, preparing presentations, and demos of AR Zappar posters along with the Google Sheets application to be displayed at exhibitions.

This study uses the validity of qualitative research in the form of credibility, transferability, dependability, and confirmability (Afiyanti, 2008). Credibility was built by a researcher who is also a mathematician in class VIII of Lazuardi Junior High School Al Falah. The researcher has taken an in-depth approach and built close relationships with each student since grade 7 . Transferability by purposive sampling or sampling aimed at grade 8 students because they are used to working on projects and discussing with researchers during the previous year. Dependability was obtained from the consistency of conversation notes during the project and by the results of interviews given to students at the end of the project.

\section{Results and Discussion}

The confirmation of this research was carried out by reflecting on the findings with research on cognitive empathy, affective empathy, and sympathy from the Adolescents Measure of Empathy and Sympathy (AMES) or the adolescent empathy and sympathy measurement scale (Vossen, Piotrowski, \& Valkenburg, 2015). Cognitive empathy refers to a student's ability to understand someone's perspective and mentality, feel the way others think, then respond with appropriate action. Affective empathy refers to the student's ability to understand someone's emotions and feelings, and to respond with appropriate emotions. Sympathy refers to the student's ability to care about the difficulties of others, and respond with appropriate actions to help.

The research process started from the researcher sparking a discussion with 8th graders about the phenomenon of dieting among teenagers by reducing food intake to avoid obesity. Meanwhile, by reducing intake, it means that adolescents reduce the energy needs that must be met so that their bodies can carry out learning activities and other activities at school. The conversation that took place was recorded as follows $(\mathrm{G}=$ teacher, $\mathrm{M}=$ student $)$.

M: "What happens to our body if we don't eat enough food?"

M1: "We get sleepy and can't concentrate"

M2: "I become hungry when studying"

G: "Okay, who had breakfast this morning and ate snack again during the break? Please raise your hand" (Only a few students raised their hands)

M3: "I had bread and milk for breakfast, then I bought 2 fried foods. That's enough"

M1: "I didn't have time for breakfast, and just bought dumplings"

G: "Why do you like eating less or not eating breakfast?"

M2: "I do not want to get fat"

M1: "I often wake up late, so less time to eat, less food" 
G: "What do you feel or think if you see your friend eating less or not eating breakfast, then in class you feel sleepy and can't concentrate?"

M5: "It's okay"

M2: "Yes, it's a pity that you can't study well. But, they're so hard-headed when we told them that it's not good to abandon what your body needs"

G: "That means, if there is a friend who is sleepy or can't concentrate, just leave it alone, we don't need to care about him?"

M1: "Nah, not really. If they can't concentrate, what if they have to work in groups? We would be in trouble too."

M5: "We care, but we don't know how."

M: "How can we know what we have been eating is enough to meet our body's energy needs?"

M4: "By calculating how much the body's energy needs are then compared with the number of calories in the food."

M2: "Actually, it can be done by calculating the calorie counter application on the Playstore, but mostly for adults and the food available is foreign food, not food in Indonesia"

G: "I guess, if we have a simple application that can display energy needs and the number of calories that come in, can it help our friends to eat so they can concentrate more in class?"

M1: "Yes, we can. If there is data and it is shown in the application, we would be able to tell our friends whether they have enough energy from the food they consumed or not."

At this stage, the researcher ignited students' cognitive empathy by trying to put the students' perspective on their friends who reduced their food intake for fear of being fat. Affective empathy is triggered by asking how you feel when you see friends who don't eat breakfast become sleepy or can't concentrate on studying during class. Sympathy is shown by asking students how much they care about the condition of their friends and what can be done to help them. The project to make an application is one solution.

The next process determines what platform is used to build the application, and Google Sheets is the choice because students are familiar with using it to build databases and process them. The application is named "Your Energy Counter". Sheets in Google Sheets are divided into 4 sheets. Sheet 1 is called "Energy Counter" for the initial part that relates to the user, it is divided into two columns, namely the column calculating energy needs and the column counting from calories the amount of intake entered. Sheet 2 is called "Formula" to place the formulations and calculation results shown in sheet 1 . Sheet 3 is called "Food" as a database of foods along with their calorie and nutritional content.

Students were divided into several divisions according to the research design, and they worked to meet the targets of their respective divisions. The form of cognitive empathy formed in each division was that each student tries to place himself in the thoughts of his fellow divisional. For example in the food database development division, which means they had to complete all types of food that must be included in the database. Initially they divided the work in alphabetical order, but given the limited time, those who had finished helped their other friends who became stressed because they had not finished yet. Cognitive and affective empathy was formed by helping others, and searching for types of food by looking into other references. Sympathy was also formed by meeting targets and tasks that must be done together. 
Then, cognitive empathy between divisions was also seen where each division tried to put the perspective of the needs of other divisions, and realized that the success of the project depends on the results of the work. The program division would not be able to complete and test the formulation if there were no food database. The AR poster design division would not be able to complete the illustration image if the program logo did not yet developed and the program could not be run. Then, the marketing division would not be able to work if there were no program that went published. Affective empathy was shown when students from one division are moved to help other divisions who had difficulty operating or when they saw a friend who got tired. If someone stopped his working, there are other students who reminded him/her while trying to help. Sympathy was formed with a strong desire to be able to publish the application so that they can help their friends at school.

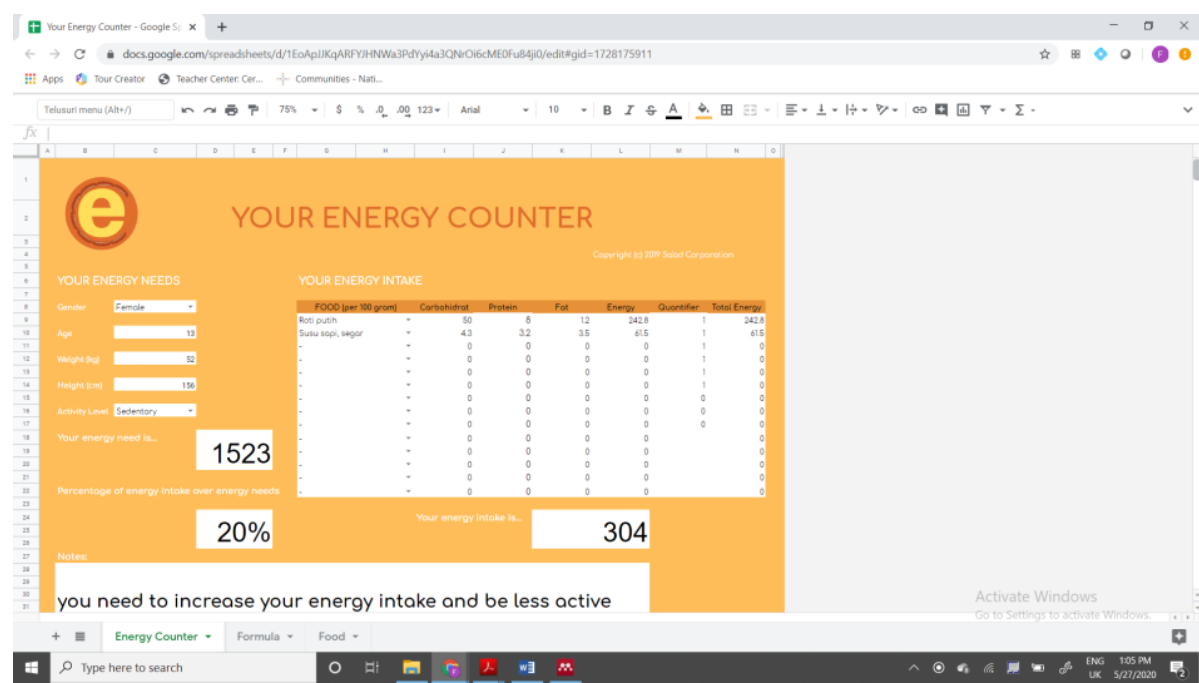

Figure 1. Display of "Your Energy Counter" application

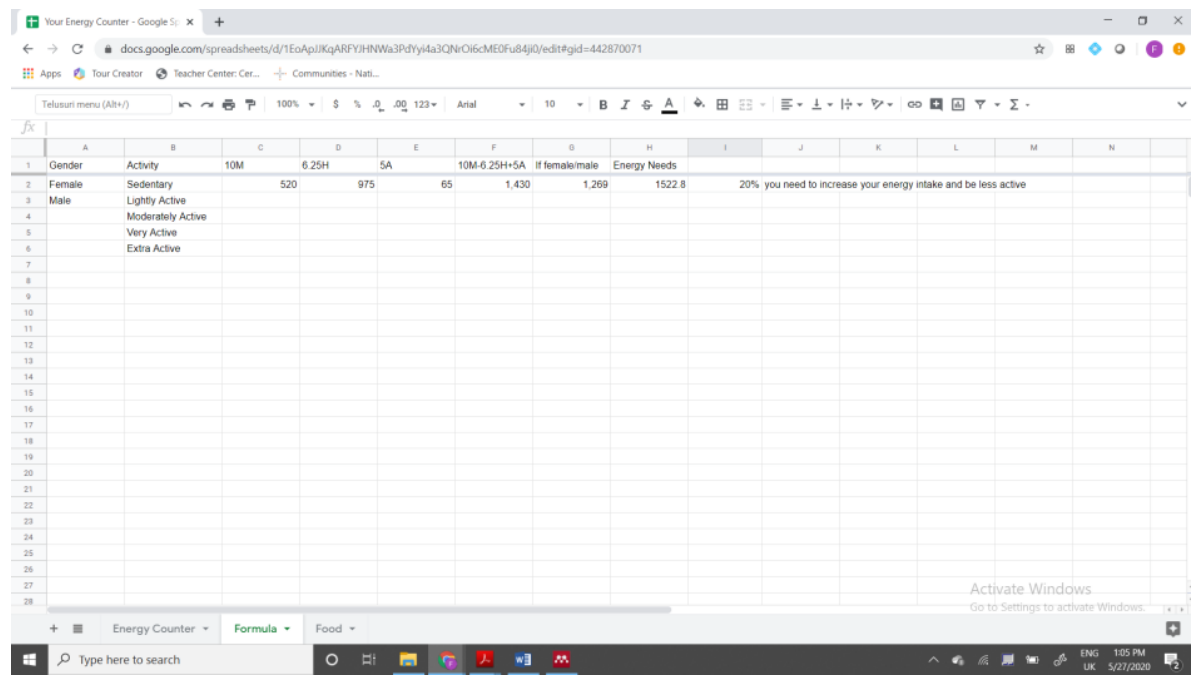

Figure 2. Display of the calculation sheet in the "Your Energy Counter" application 


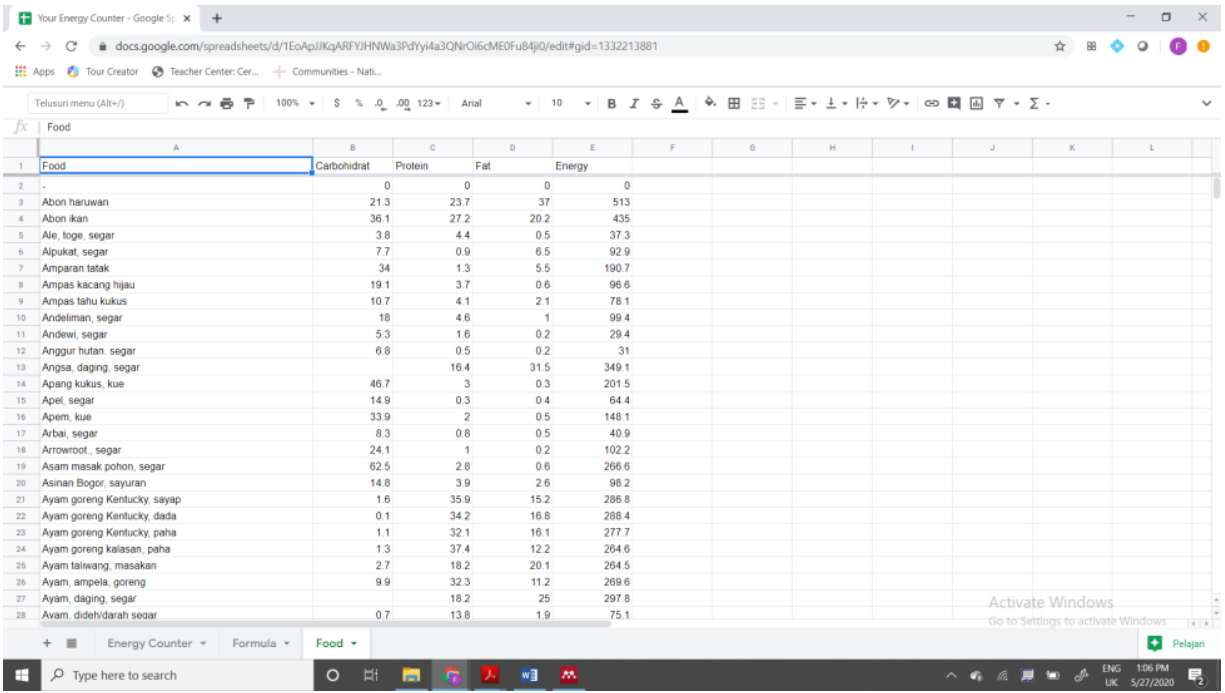

Figure 3. Display of Indonesian food nutrition data sheet in "Your Energy Counter" application

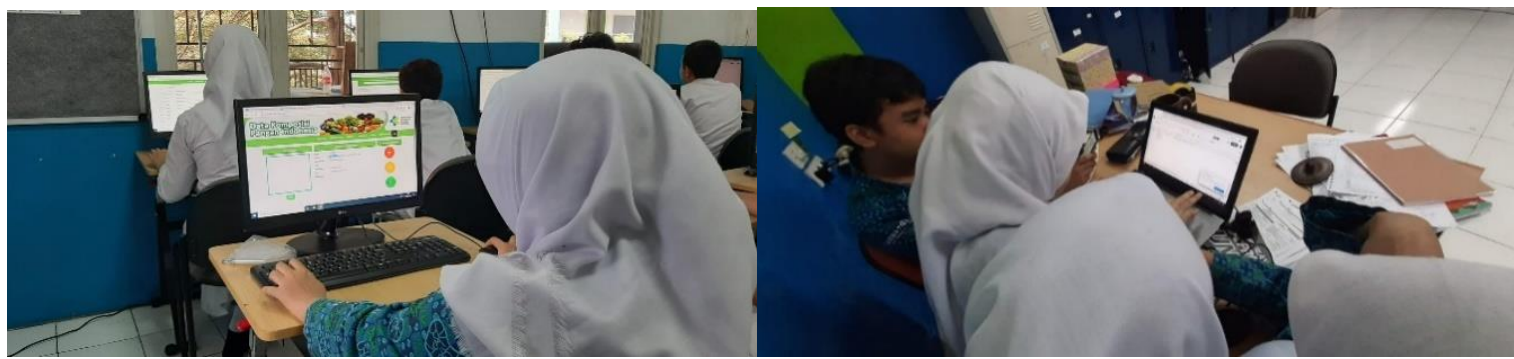

Figure 4. Food Database Development Division and Programmers at Class VIII Lazuardi Al Falah Junior High School, Depok, collecting nutritional data for various types of food
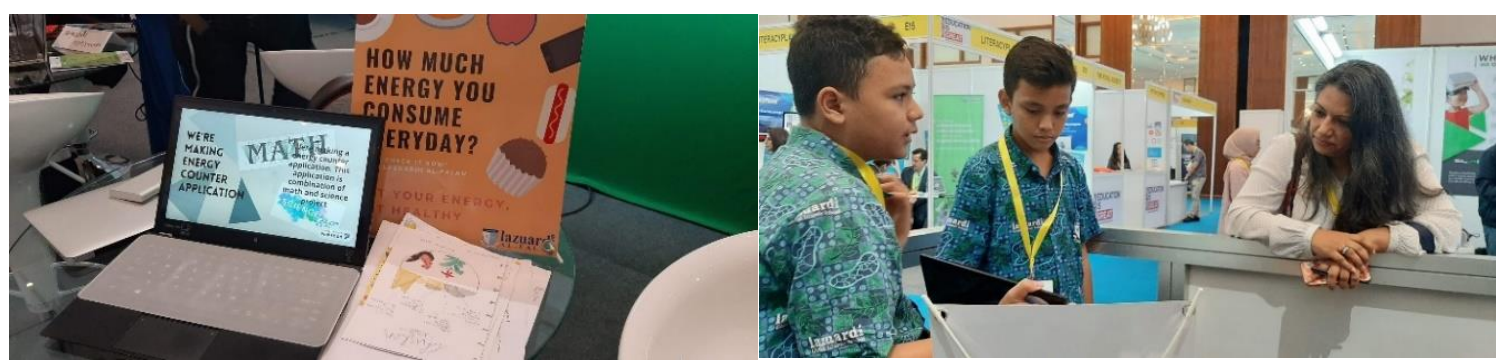

Figure 5. Design and Marketing Division at Class VIII Lazuardi Junior High School Al Falah Depok presenting the application at GESS Indonesia 2019

To gain consistency, whether students feel that by working on this project they had developed their empathy, a digital form with several questions was distributed to gain students' feedback from the learning process.

The first question, "At the beginning of the project, do you understand what empathy means? Explain your answer." Only 3 out of 11 students answered "Yes" and here are some of their responds.

Table 1. Students' Understanding of Empathy

\begin{tabular}{ll} 
Respond 1 & "No. I do not know what empathy means. Is it the same as pity?" \\
\hline Respond 2 & "No. I think it's just a feeling."
\end{tabular}


Respond $3 \quad$ "Yes. It's about placing ourselves in other people's shoes so we know their thinking and feeling and we do something about it."

This is consistent with the teacher's action in the beginning of the lesson to give driving questions to talk about their friends' conditions and feelings because their affective empathy had not been developed yet.

The second question, "Do you know what actions that you can do when you empathize to someone else? Explain what they are." 5 out of 11 students answered "Yes" and here are some of their responds.

Table 2. Students' Perception of Empathetic Action

\begin{tabular}{ll}
\hline Respond 1 & "I help them, maybe?" \\
\hline Respond 2 & "I will cry when I imagine how bad the situation of other people." \\
\hline Respond 3 & $\begin{array}{l}\text { "I give advice to help them solving their problems. But I do not know if it's an empathetic } \\
\text { action." }\end{array}$
\end{tabular}

This is also consistent when the teacher continued to steer the discussion to what they can do about their friends' experience. This was the time when cognitive empathy stated to develop in the planning stage. Students started mentioning what they could do and how they would design the Energy Counter application.

The third question, "Do you think that steps you chose in this project is an act of empathy? Explain your answer." 11 out of 11 students answered "Yes" and here are some of their responds.

Table 2. Students' Perception of Empathetic Action

Respond $1 \quad$ "The Your Energy Counter is a math project related to science. This project is planned to be in the form of an application that can calculate how many calories from the food you consume, but for one reason or another the form of the application has not been realized. This project is in the form of a simple application using a Google Spread Sheet that has been arranged in such a way as to be able to select, enter, and calculate the data that has been given. The data provided is in the form of calories from foods that are usually consumed, the source of data (calories from food) is obtained from panganku.org site. The data taken in the form of fat, protein, carbohydrates and calculated by calculating calories that we have learned in science lessons about calories. This project is a joint project (one class) which is divided into several work divisions. So, with this application, we can help our friends to have a healthier body, and I think that's an act of empathy."

Respond $2 \quad$ "In this project we created a tool that can find out how many calories we get from the foods we eat. We built this tool in Google Sheets and use various formulas. Users will be asked to enter their weight, gender, age, height, and what foods they eat in that one day. This means we can help our friends find out if he/she is overweight or underweight and what to do if his or her energy is more or less than is needed. I think it's an act of empathy because I can help them instead of just knowing what they feel or think."

Respond 3 "I think because we did and developed something, I can say that it's an act of empathy. We did not just wait and did nothing, right?"

At this stage the students have understood their mission and what they would achieve. By engaging in the application making process, they perceived what they did as an act of empathy. The cognitive empathy had progressed to the execution stage. 
The fourth question: "In your opinion, does this project allow you to empathize with your friends? (Answer Yes/No, then explain why)." 11 out of 11 students answered "Yes" and here are some reasons.

Table 4. Students' Reasons Why Projects Make Them Feeling Empathetic

\begin{tabular}{ll} 
Reason 1 & $\begin{array}{l}\text { "We worked on this project together, so we are aware of every obstacle our classmates } \\
\text { are having and try to help out if needed." }\end{array}$ \\
\hline Reason 2 & $\begin{array}{l}\text { "Please help in making this project this is usually done, because we both understand that } \\
\text { the task/project we are working on cannot be done alone." }\end{array}$ \\
\hline Reason 3 & "Yes, because it can foster empathy and help each other while working on this project" \\
\hline
\end{tabular}

At this stage, students had developed a recognition of their affective and cognitive empathy, in which they perceived the situations, what the others' feelings and what actions they could act in responding to the situation.

The fifth question is a multiple choice as follows, "Which do you think is more important: A. Can you use technology rather than cultivate empathy? B. Can you cultivate empathy instead of using technology? C. Can you use technology that fosters empathy?" Out of 11 students, 10 answered $\mathrm{C}$ and 1 answered $\mathrm{B}$.

The following are the reasons for the students' answers to the questions above.

Table 5. Reasons for Using Technology that Grows Empathy

Reason 1 "Because I can't work on this tool alone, I need someone else's help to work together.
After all, a balanced thing is the best thing than being concerned with something else.
Utilizing technology is important, but if we can work together with each other so that we
can use technology more easily why not?"

Reason $2 \quad$ "In this day and age, many people use technology. If the technology we use can foster empathy in many people, then the programs we create can change their lives for the better."

Reason $3 \quad$ "Utilizing technology is very important in this day and age. However, that empathy often
fades because of the technology itself. Therefore, we must be able to take advantage of
technology that fosters empathy.

Reason 4

"So that what we do can be useful and used by many people."

In the context of this project-based learning, empathy is generated by conditioning students to be able to see the needs of their friends and feel when the friend is having difficulties when trying to fulfill whatever is needed. By utilizing design engineering project activities, having a common goal in making an application published through an exhibition event makes all students have the same desire to work together to realize the application (Van Mechelen et al., 2019).

The majority of students chose the phrase "using technology to foster empathy" as more important to them indicating that the use of technology media in their activities is a must for today's generation (Jonassen, Peck, \& Wilson, 1999). However, this does not mean that teachers must always use technology to make students want to be actively involved. It means students will be interested if the lessons we provide integrate with technology (Henrie, Halverson, \& Graham, 2015). 


\section{Conclusion}

This STEAM project based learning in mathematics class, shows students' development in their ability to empathize. Start from the beginning where they are not aware of empathy, then at the end of project, they can develop both their cognitive and affective empathy (Maxwell and DesRoches, 2010) using STEAM learning. The use of technology in STEAM projects is used as a medium so that students become interested and motivated to work. As Freudenthal (1968) suggested more than half a century ago that mathematics should be taught with usefulness, it would be better if mathematics teachers could design a projectbased learning that not only shows how mathematical concepts are applied, but also develops empathy to students.

\section{Acknowledgment}

Special appreciations were bestowed upon students, teachers, and the principal of SMP Lazuardi Al Falah Depok as well as the board of directors of Yayasan Bhakti Setia Jaya who were very instrumental in supporting the projects and data collection for this research.

\section{References}

Afiyanti, Y. (2008). Validitas dan reliabilitas dalam penelitian kualitatif. Jurnal Keperawatan Indonesia, 12(2), 137-141.

Auliyah, A., \& Flurentin, E. (2016). Efektifitas Penggunaan Media Film untuk Meningkatkan Empati Siswa Kelas VII SMP. Jurnal Kajian Bimbingan Dan Konseling, 1(1), 19-26.

Ayuni, R. D., Siswati, S., \& Rusmawati, D. (2013). Pengaruh Storytelling terhadap Perilaku Empati Anak. Jurnal Psikologi, 12(2), 121-130.

Belman, J., \& Flanagan, M. (2010). Designing games to foster empathy. International Journal of Cognitive Technology.

Boltz, L. O., Henriksen, D., \& Mishra, P. (2014). Rethinking Technology \& Creativity in the 21st Century: Empathy through Gaming - Perspective Taking in a Complex World. TechTrends. https://doi.org/10.1007/s11528-015-0895-1

Burns, H. D., \& Lesseig, K. (2017). Empathy in middle school engineering design process. Proceedings - Frontiers in Education Conference, FIE. https://doi.org/10.1109/FIE.2017.8190669

Fellus, O. O. (2019). Connecting the dots: toward a networked framework to conceptualizing identity in mathematics education. ZDM - Mathematics Education. https://doi.org/10.1007/s11858-019-01053-9

Freudenthal, H. (1968). Why to teach mathematics so as to be useful. Educational Studies in Mathematics. https://doi.org/10.1007/BF00426224 
Friesem, Y. (2016). Empathy for the digital age: Using video production to enhance social, emotional, and cognitive skills. In Emotions, technology, and behaviors (pp. 21-45). Elsevier.

Goldstein, T. R., \& Winner, E. (2012). Enhancing Empathy and Theory of Mind. Journal of Cognition and Development. https://doi.org/10.1080/15248372.2011.573514

Harris, J. A., \& Benedict, F. G. (1918). A Biometric Study of Human Basal Metabolism. Proceedings of the National Academy of Sciences. https://doi.org/10.1073/pnas.4.12.370

Harris, R., \& Foreman-Peck, L. (2004). 'Stepping into other peoples' shoes': Teaching and assessing empathy in the secondary history curriculum. International Journal of Historical Learning, Teaching and Research, 4(2), 98-111.

Henrie, C. R., Halverson, L. R., \& Graham, C. R. (2015). Measuring student engagement in technology-mediated learning: A review. Computers and Education. https://doi.org/10.1016/j.compedu.2015.09.005

Jonassen, D. H., Peck, K. L., \& Wilson, B. G. (1999). Learning with technology: A constructivist perspective. Special Education.

Kemendikbud, R. I. (2017). Konsep dan Pedoman Penguatan Pendidikan Karakter. Jakarta. Peraturan Presiden (Perpres) Nomor, 87.

Kurukkan, A. (2015). Why High School Students Feel Mathematics Difficult? An Exploration of Affective Beliefs. Online Submission.

Lortie-Forgues, H., Tian, J., \& Siegler, R. S. (2015). Why is learning fraction and decimal arithmetic so difficult? Developmental Review. https://doi.org/10.1016/j.dr.2015.07.008

Maxwell, B., \& DesRoches, S. (2010). Empathy and social-emotional learning: Pitfalls and touchstones for school-based programs. New Directions for Child and Adolescent Development, 2010(129), 33-53. doi:10.1002/cd.274

Mcdonald, N. M., \& Messinger, D. S. (2013). The Development of Empathy: How, When and Why. Free Will, Emotions, and Moral Actions: Philosophy and Neuroscience in Dialogue.

Ojose, B. (2011). Mathematics literacy: are we able to put the mathematics we learn into everyday use? Journal of Mathematics Education.

Piñon, M., \& Forestier, A. (2018). Lack of empathy in teenagers, a weakness in the therapeutic relationship. Soins https://doi.org/10.1016/j.spsy.2018.04.013

Sembiring, R. K., Hadi, S., \& Dolk, M. (2008). Reforming mathematics learning in Indonesian classrooms through RME. ZDM - International Journal on Mathematics Education. https://doi.org/10.1007/s11858-008-0125-9 
Van Mechelen, M., Schut, A., Gielen, M., \& Klapwijk, R. (2018). Developing children's empathy in co-design activities: A pilot case study. IDC 2018 - Proceedings of the 2018 ACM Conference on Interaction Design and Children. https://doi.org/10.1145/3202185.3210797

Van Mechelen, M., Schut, A., Gielen, M., \& Södergren, A. C. (2019). Children's assessment of co-design skills: Creativity, empathy and collaboration. Proceedings of the 18th ACM International Conference on Interaction Design and Children, IDC 2019. https://doi.org/10.1145/3311927.3325334

Vossen, H. G. M., Piotrowski, J. T., \& Valkenburg, P. M. (2015). Development of the Adolescent Measure of Empathy and Sympathy (AMES). Personality and Individual Differences. https://doi.org/10.1016/j.paid.2014.09.040

Wewengkang, D. B. P., \& Moordiningsih, M. (2016). Studi Fenomenologi Konteks Budaya Jawa dan Pengaruh Islam: Situasi Psikologis Keluarga dalam Membangun Empati pada Remaja. Indigenous: Jurnal Ilmiah Psikologi, 1(1), 1-11 